\title{
TU/e EN⿴HONE

\section{Plasma-deposited hybrid silica membranes with a controlled retention of organic bridges}

\section{Citation for published version (APA):}

Tchoua Ngamou, P. H., Overbeek, J. P., Kreiter, R., Veen, van, H. M., Vente, J. F., Wienk, I. M., Cuperus, P. F., \& Creatore, M. (2013). Plasma-deposited hybrid silica membranes with a controlled retention of organic bridges. Journal of Materials Chemistry A, 1(18), 5567-5576. https://doi.org/10.1039/C3TA00120B

DOI:

10.1039/C3TA00120B

Document status and date:

Published: 01/01/2013

\section{Document Version:}

Publisher's PDF, also known as Version of Record (includes final page, issue and volume numbers)

\section{Please check the document version of this publication:}

- A submitted manuscript is the version of the article upon submission and before peer-review. There can be important differences between the submitted version and the official published version of record. People interested in the research are advised to contact the author for the final version of the publication, or visit the $\mathrm{DOI}$ to the publisher's website.

- The final author version and the galley proof are versions of the publication after peer review.

- The final published version features the final layout of the paper including the volume, issue and page numbers.

Link to publication

\section{General rights}

Copyright and moral rights for the publications made accessible in the public portal are retained by the authors and/or other copyright owners and it is a condition of accessing publications that users recognise and abide by the legal requirements associated with these rights.

- Users may download and print one copy of any publication from the public portal for the purpose of private study or research.

- You may not further distribute the material or use it for any profit-making activity or commercial gain

- You may freely distribute the URL identifying the publication in the public portal.

If the publication is distributed under the terms of Article $25 \mathrm{fa}$ of the Dutch Copyright Act, indicated by the "Taverne" license above, please follow below link for the End User Agreement:

www.tue.nl/taverne

Take down policy

If you believe that this document breaches copyright please contact us at:

openaccess@tue.nl

providing details and we will investigate your claim. 
Cite this: J. Mater. Chem. A, 2013, 1, 5567

Received 9th January 2013 Accepted 5th March 2013

DOI: $10.1039 / c 3 t a 00120 b$

www.rsc.org/MaterialsA

\section{Plasma-deposited hybrid silica membranes with a controlled retention of organic bridges}

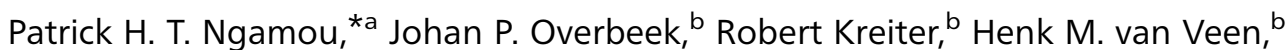 \\ Jaap F. Vente, ${ }^{\mathrm{b}}$ Ingrid M. Wienk, ${ }^{\mathrm{c}}$ Petrus F. Cuperus ${ }^{\mathrm{c}}$ and Mariadriana Creatore ${ }^{\star a}$
}

Hybrid organically bridged silica membranes are suitable for energy-efficient molecular separations under harsh industrial conditions. Such membranes can be useful in organic solvent nanofiltration if they can be deposited on flexible, porous and large area supports. Here, we report the proof of concept for applying an expanding thermal plasma to the synthesis of perm-selective hybrid silica films from an organically bridged monomer, 1,2-bis(triethoxysilyl)ethane. This membrane is the first in its class to be produced by plasma enhanced chemical vapor deposition. By tuning the plasma and process parameters, the organic bridging groups could be retained in the separating layer. This way, a defect free film could be made with pervaporation performances of an $n$-butanol-water mixture comparable with those of conventional ceramic supported membranes made by sol-gel technology (i.e. a water flux of $\sim 1.8 \mathrm{~kg}$ $\mathrm{m}^{-2} \mathrm{~h}^{-1}$, a water concentration in the permeate higher than $98 \%$ and a separation factor of $>1100$ ). The obtained results show the suitability of expanding thermal plasma as a technology for the deposition of hybrid silica membranes for molecular separations.

\section{Introduction}

Generally described as "clean technology", membrane based molecular separations offer an energy-efficient alternative to conventional separation processes such as distillation. Specific examples include the recovery of organic compounds from aqueous solutions, separation of organic mixtures and dehydration of organic solvents like bio-ethanol. One of the possible membrane processes that are suitable for these applications is pervaporation. This latter is characterized by selective evaporation of, preferably, the minor component, through a membrane, typically carried out at elevated temperatures (150$200{ }^{\circ} \mathrm{C}$ ). Several materials including polymers like polyimide, ${ }^{1}$ polyamide, ${ }^{2}$ polyvinyl alcohol, ${ }^{3}$ and inorganic materials like silica, ${ }^{1,3,4}$ zeolite $^{4-6}$ and titania/zirconia ${ }^{7,8}$ have been intensively studied. However, these membranes generally display low stability when the separation occurs in the presence of aggressive solvents, at high water content or at high temperature. An alternative membrane process is nanofiltration. This is a pressure driven process in which the liquid feed is not evaporated and, in general, the major component of the mixture is allowed through the membrane. Currently, there is a general trend

\footnotetext{
aDepartment of Applied Physics, Eindhoven University of Technology, $5600 \mathrm{MB}$ Eindhoven, The Netherland.E-mail: p.h.tchoua.ngamou@tue.nl; m.creatore@tue.nl; Tel: +31 40-247 4223

${ }^{b} E C N$, Energy research Centre of the Netherlands, P.O.Box 1, 1755 ZG Petten, The Netherlands

${ }^{c}$ SolSep BV, 7333 NW, Apeldoorn, The Netherlands
}

towards lower and sharper cut-off values and towards more aggressive organic solvents. Polymeric membranes are not anticipated to meet these strict performance requirements as they suffer from swelling thereby limiting the application window. ${ }^{9}$ Crosslinking of polymeric membranes has been shown to increase their chemical and thermal stability. ${ }^{10,11}$ However, this is often at the expense of a decrease in permeability. Ceramic membranes are often too hydrophilic to be able to transport non-polar solvents because of their non-wetting behavior. Grafting using fluorinated silane precursors with a terminating organic group has been widely used to modify the surface-solvent interactions. ${ }^{12,13}$ Again, the resulting membranes have a limited stability.

Recently, it was reported that the incorporation of organic bridges that covalently bond with silicon increases the hydrothermal stability of silica membranes under pervaporation conditions. For example, an unprecedented lifetime of 1000 days in the dehydration of $n$-butanol at $150{ }^{\circ} \mathrm{C}$ has been reported $^{14}$ for an organosilica silica membrane prepared by sol-gel condensation of the bridged precursor 1,2-bis(triethoxysilyl)ethane (BTESE) $(\mathrm{EtO})_{3} \mathrm{Si}\left(\mathrm{CH}_{2}\right)_{2} \mathrm{Si}(\mathrm{EtO})_{3}$. Moreover, these membranes are stable in aprotic solvents and at $\mathrm{pH}$ as low as 2 . An improved hydrothermal stability was also reported ${ }^{15}$ in gas separations. This exceptional stability was partially ascribed to the improved mechanical properties of the silica network because of the presence of silicon-hydrocarbon-silicon bridges. ${ }^{16}$ In parallel, the potential associated with the incorporation of other bridge moieties ${ }^{17}$ and terminal groups ${ }^{18}$ has been reported. Recently, we have pursued the development of a 
solvent resistant nanofiltration membrane based on the same chemical principle. An expensive and complex support ${ }^{\mathbf{1 9}}$ is not required for this low temperature process and can be replaced by a relatively low-cost polymeric support. This offers the additional benefit that conventional module concepts, such as spiral wounds, can be used, facilitating a reduced time-to-market.

Sol-gel technology is a well-established route for the preparation of hybrid membranes. An alternative approach is plasmaenhanced chemical vapor deposition (PECVD) which has the benefits of being a one-step, substrate-independent technique and compatible with large area processing. Thin silica-like films deposited by PECVD have been used as low- $k$ dielectric films in microelectronics ${ }^{20-22}$ and barrier/protective layers. ${ }^{23-25}$ The expanding thermal plasma chemical vapor deposition (ETPCVD) has emerged as a valid technique for the deposition of several thin materials including silica or silica-like films, ${ }^{26}$ amorphous carbon ${ }^{27,28}$ and $\mathrm{ZnO}^{29,30}$ The main difference between the ETP-CVD and the conventional RF-PECVD is the absence of ion bombardment during the deposition, due to the very low electron temperature in the downstream region, therefore the limited developed self-bias voltage, i.e. $2-3 \mathrm{~V} .{ }^{31}$ The remote character of the ETP-CVD also offers the possibility to tune the film properties, in terms of chemical composition through an independent control of the plasma and other process parameters. For instance, the tunability of carbon-containing silica films deposited from hexamethyldisiloxane ( $\mathrm{HMDSO}, \mathrm{Me}_{3} \mathrm{Si}-\mathrm{O}-\mathrm{SiMe}_{3}$ ) $-\mathrm{O}_{2}-\mathrm{Ar}$ mixtures by means of the ETPCVD has been demonstrated before. ${ }^{32-37}$ Creatore et al. ${ }^{37}$ studied the reaction mechanisms involved in Ar/HMDSO plasma. In the ETP technique, the dissociation of the organosilicon precursor into film depositing radicals is initiated by charge exchangedissociative recombination reactions between the injected precursor and the argon ions and electrons emanating in the downstream region from the arc nozzle, according to eqn (1)-(3),

$$
\begin{gathered}
\mathrm{Me}_{3} \mathrm{Si}-\mathrm{O}-\mathrm{SiMe}_{3}+\mathrm{Ar}^{+} \rightarrow\left[\mathrm{Me}_{3} \mathrm{Si}-\mathrm{O}-\mathrm{SiMe}_{3}\right]^{+*}+\mathrm{Ar} \\
\mathrm{Me}_{3} \mathrm{Si}-\mathrm{O}-\mathrm{SiMe}_{3}+\mathrm{Ar}^{+} \rightarrow \mathrm{Me}_{3} \mathrm{Si}-\mathrm{O}-\mathrm{SiMe}_{2}+\mathrm{Ar}+\mathrm{Me} \\
{\left[\mathrm{Me}_{3} \mathrm{Si}-\mathrm{O}-\mathrm{SiMe}_{3}\right]^{+*}+\mathrm{e}^{-} \rightarrow \mathrm{Me}_{3} \mathrm{Si}-\mathrm{O}-\mathrm{SiMe}_{2}+\mathrm{Me}}
\end{gathered}
$$

The products of reactions (2) and (3) can undergo further dissociation reactions with argon ions and electrons, leading to $\mathrm{Si}-\mathrm{O}$ bond dissociation, and to further abstraction of methyl radicals. The established reaction channels indicate the importance of the argon ion-to-deposition precursor ratio to control the developed plasma chemistry and film structure/ composition.

In this contribution, we report on the application of the ETPCVD as a technique for the deposition of a perm-selective hybrid organically bridged silica layer from an argon-BTESE mixture on a polyamide-imide support. The main goal is to prepare stable polymeric-supported hybrid silica membranes by promoting the retention of the silicon-hydrocarbon-silicon bridge from the initial monomer. Replacing part of the hydrolysable $\mathrm{Si}-\mathrm{O}-\mathrm{Si}$ network in the silica matrix by $\mathrm{Si}-\mathrm{CH}_{2}-\mathrm{CH}_{2}-\mathrm{Si}$ bonds is wellknown $^{38-40}$ to improve the hydrothermal stability of the silica membrane. Based on an extensive film characterization by means of X-ray photoelectron spectroscopy, Fourier transform infrared spectroscopy and Rutherford backscattering, coupled with insights into the plasma chemistry and BTESE molecule dissociation paths, it was found that by modifying the BTESE-toAr ion ratio, the dissociation paths of BTESE in the thermal plasma can be controlled and the retention percentage of the silicon-hydrocarbon-silicon bridge optimized up to a value of $30 \%$. As a proof-of-principle, the membranes were used for the pervaporation dehydration of the butanol-water (95/5 wt\%) feed mixture at $95{ }^{\circ} \mathrm{C}$. The results were compared with those of commercial ceramic supported membranes.

\section{Experimental}

\section{Membrane preparation}

In this study, hybrid organically bridged silica films based on BTESE were deposited on crystalline silicon wafers as well as on non-selective polyamide-imide substrates supplied by SolSEP BV, a membrane manufacturer in Netherlands. A schematic representation of the ETP-CVD setup is shown in Fig. 1. A detailed description of the experimental setup can be found elsewhere. ${ }^{32-37}$

In brief, an argon ( $\left.\Phi_{\mathrm{Ar}}=20 \mathrm{sccs}\right)$ plasma was ignited using an arc current of $25 \mathrm{~A}$ in a wall stabilized dc-cascaded arc operating at a pressure of 290 mbar. The thermal plasma expands through the nozzle into the deposition chamber kept at a pressure of 0.1 mbar. The BTESE precursor (Sigma-Aldrich, 98\%) was vaporized using a Bronkhorst-controlled evaporation module (CEM W202), maintained at $150{ }^{\circ} \mathrm{C}$, and carried by inert argon $(3.3 \mathrm{sccs})$ to the reactor. To prevent condensation of BTESE, all gas lines were trace heated to $160{ }^{\circ} \mathrm{C}$. The BTESE vapor (flow rate 2.3-46.2 $\mathrm{sccm}$ ) was injected by means of a punctured ring situated at $5 \mathrm{~cm}$ from the nozzle. The film deposition takes place on a substrate situated at $60 \mathrm{~cm}$ from the nozzle and kept at room temperature.

\section{Membrane characterization}

Several analytical methods were used to characterize the deposited hybrid silica layers. Characterization techniques such

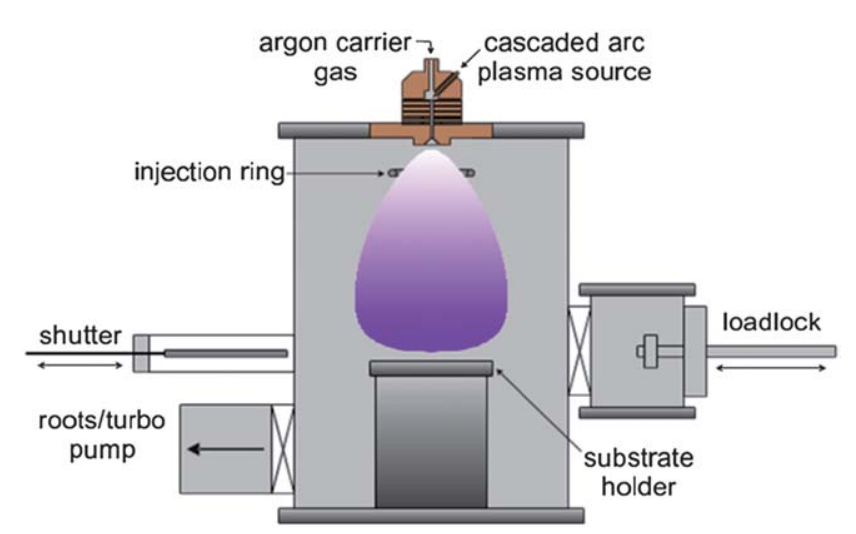

Fig. 1 Schematic of the expanding thermal plasma set-up used for the deposition of hybrid silica films. 
as Fourier transform infrared (FTIR) spectroscopy, Rutherford back scattering and spectroscopic ellipsometry were applied to the films deposited on Si (001) wafers.

Infrared spectroscopy was performed using a Bruker Vector 22 FTIR spectrometer operating in transmission mode. The resolution of the spectrometer was set at $4 \mathrm{~cm}^{-1}$ and all spectra were collected in the range of $400-4000 \mathrm{~cm}^{-1}$, baseline corrected and normalized to the film thickness for comparison. The deconvolution of FTIR absorption bands was performed using the "fit multiple peaks" function of the ORIGIN 8.5 software and peak positions were held constant and assigned according to the literature.

Optical analysis was performed in situ and ex situ by means of a spectroscopic UV-visible ellipsometer (J. A. Woollam M2000U). In situ measurements were carried out at an incident angle of $75^{\circ}$, while ex situ measurements (within $30 \mathrm{~min}$ of exposure to ambient air) were performed at different angles of incidence $\left(60^{\circ}, 70^{\circ}\right.$ and $\left.75^{\circ}\right)$ using a rotating compensator ellipsometer. A model consisting of a silicon substrate, a native $\mathrm{SiO}_{2}$ layer $(2 \mathrm{~nm})$ and the hybrid silica film modeled with the Cauchy dispersion formula coupled with the absorption tail in the UV range was used to fit the measured complex reflectance ratio (parameterized by the amplitude component, $\Psi$, and the phase difference, $\Delta$ ) and determine the refractive index, the film thickness and the absorption coefficient.

X-ray photoelectron spectroscopy (XPS) measurements were performed using a Thermo Fisher Scientific KA 1066 photoelectron spectrometer equipped with an Al K-alpha (1253.6 eV) source for excitation in the analysis chamber under high vacuum $\left(\sim 3 \times 10^{-8} \mathrm{mbar}\right)$. The sample charging was corrected with respect to the binding energy of the C1s core level $(284.6 \mathrm{eV}) .{ }^{41}$ The relative quantification was achieved by using the atomic sensitivity factor provided by the manufacturer. The atomic ratios and surface concentrations were quantitatively determined from the area of the Si2p, C1s, and O1s peaks after a smart-type background subtraction, while the peak deconvolution was achieved using a mixed Gaussian and Lorentzian function and keeping the full-width-half-maximum (FWHM) constant.

Contact angle measurements were performed at room temperature by the sessile drop method using a contact angle goniometer equipped with a video camera recording system operated using software for drop-shape analysis. The water droplet with a volume of $3 \mu \mathrm{l}$ was placed at 5 different regions of the surface of the deposited film. The contact angle was measured for each and the average value was taken. The compositional film analysis was achieved by means of Rutherford back scattering (RBS). The measurements were performed in the ion accelerator of AccTec BV (Eindhoven University of Technology) using a mono-energetic beam of two $\mathrm{MeV}^{4} \mathrm{H}^{+}$ions sampled at normal incidence and the spectra were recorded in channeling geometry.

\section{Membrane testing}

Pervaporation experiments were performed using an in-house made batch test installation as already described elsewhere. ${ }^{\mathbf{1 0}}$
The employed pervaporation cell for membrane tests was about $5 \mathrm{~cm}^{2}$. Briefly, the feed, containing $5 \%$ of water in $n$-butanol, was heated at $95{ }^{\circ} \mathrm{C}$, while the permeate pressure was kept at 10 mbar by means of a vacuum pump. The water concentrations in the feed and the permeate were determined by Karl-Fischer titrations and the refractive index under ambient conditions (Mettler Toledo RA510M), respectively. The membrane performance was characterized in terms of water flux $\left(J_{\mathrm{H}_{2} \mathrm{O}}: \mathrm{kg} \mathrm{m}^{-2}\right.$ $\mathrm{h}^{-1}$ ) as shown below

$$
J_{\mathrm{H}_{2} \mathrm{O}}=\frac{Q_{\mathrm{H}_{2} \mathrm{O}}}{A t}
$$

where, $Q_{\mathrm{H}_{2} \mathrm{O}}$ is the mass of permeated water collected over a time $t$ and $A$ is the effective membrane area for permeation. The separation factor, $\alpha$, is defined as

$$
\alpha=\frac{Y_{\mathrm{w}} / Y_{\mathrm{b}}}{X_{\mathrm{w}} / X_{\mathrm{b}}}
$$

where $Y$ and $X$ are the weight fractions of water (w) and $n$ butanol (b) in the permeate and feed solutions, respectively.

\section{Results and discussion}

\section{Optical analysis}

The influence of the monomer flow rate, $\Phi_{\mathrm{BTESE}}$, on the deposition rate and the refractive index (at $632.8 \mathrm{~nm}$ ) of the layers is shown in Fig. 2. The deposition rate increases linearly with the increase of $\Phi_{\mathrm{BTESE}}$ until $\Phi_{\mathrm{BTESE}} \approx 35 \mathrm{sccm}$, above which a plateau is reached.

The increase of the deposition rate is due to the decrease of the residence time of the BTESE vapor in the thermal plasma. Fig. $2 \mathrm{~b}$ shows the variation of the in situ $\left(n_{\mathrm{in}}\right)$ and ex situ $\left(n_{\mathrm{ex}}\right)$ refractive index $(n)$ as a function of $\Phi_{\mathrm{BTESE}}$. Both $n_{\mathrm{in}}$ and $n_{\mathrm{ex}}$ decrease as $\Phi_{\text {BTESE }}$ increases untill $\Phi_{\mathrm{BTESE}} \approx 25 \mathrm{sccm}$, above which, they appear to be independent of $\Phi_{\mathrm{BTESE}}$. The reduced value of the refractive index, for $\Phi_{\mathrm{BTESE}}<25 \mathrm{sccm}$, after exposure
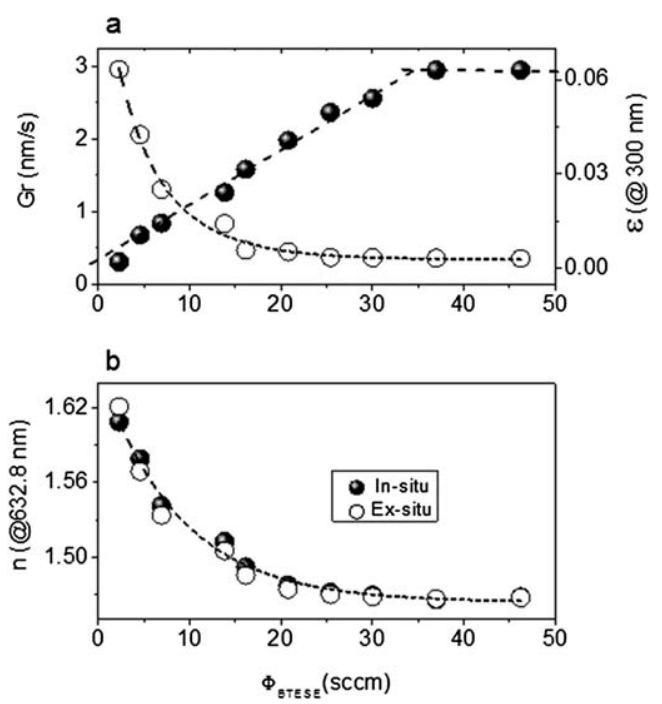

Fig. 2 (a) Deposition rate, Gr, (filled circles), absorption coefficient, $\varepsilon$, (open circles) and (b) refractive index, $n$, as a function of $\Phi_{\text {BTESE}}$. 
to ambient air suggests ageing phenomena, including water adsorption in the film porosity and oxidation of the as-deposited films. The decrease of $n$ as $\Phi_{\text {BTESE }}$ increased could partially be ascribed to the decrease in carbon content. In fact, the extinction coefficient determined at $350 \mathrm{~nm}$ as a function of $\Phi_{\text {BTESE }}$ shows the same behavior as the refractive index. This indicates that the deposited films become more transparent as $\Phi_{\text {BTESE }}$ increases. In our previous study, ${ }^{\mathbf{4 2}}$ the argon ion flux, $\Phi_{\mathrm{Ar}^{+}}$, determined on the basis of Langmuir probe measurements, was found to be approximately $25 \mathrm{sccm}$ for the experimental conditions used in this work. This means that the saturation of the refractive index for $\Phi_{\mathrm{BTESE}} \geq 25 \mathrm{sccm}$ can be explained by the quantitative consumption of $\left(\mathrm{Ar}^{+}, \mathrm{e}^{-}\right)$in the plasma due to the injected BTESE flow, according to the charge exchange-dissociative recombination reaction as described in the Introduction part (eqn (1)-(3)). It is worth noting that the refractive index at high $\Phi_{\mathrm{BTESE}}$ values is close to that of the thermal silicon dioxide $\left(n_{\mathrm{SiO}_{2}} \sim 1.46\right)$. However, as the RBS and FTIR results indicate, a refractive index close to that of thermal silicon dioxide does not necessarily exclude the presence of porosity and carbon in the deposited films.

\section{Film chemical (IR) analysis}

Further changes in the film structure induced by increasing $\Phi_{\text {BTESE }}$ can be assessed by analyzing the FTIR spectra of the deposited films, reported together with the spectrum of the liquid BTESE precursor, in Fig. 3. Band assignments were taken from the literature $\mathrm{e}^{22,43-51}$ and are summarized in Table 1. The FTIR spectra of the deposited films are characterized by the appearance of absorption bands such as -OH stretching (3100$\left.3600 \mathrm{~cm}^{-1}\right), \mathrm{Si}-\mathrm{H}_{x}$ stretching $\left(2150-2300 \mathrm{~cm}^{-1}\right), \mathrm{Si}-\left(\mathrm{CH}_{3}\right)_{x}(x=$ 1-2) symmetric bending (1250-1275 $\left.\mathrm{cm}^{-1}\right)$, Si-O-Si asymmetric stretching (1000-1200 $\left.\mathrm{cm}^{-1}\right)$, Si-OH bending ( $\left.950 \mathrm{~cm}^{-1}\right), \mathrm{Si}-$ O-Si bending $\left(880 \mathrm{~cm}^{-1}\right)$ with a shoulder at around $840 \mathrm{~cm}^{-1}$ corresponding to $\mathrm{Si}-\mathrm{CH}_{3}$ rocking mode.

Si-O-H groups. The broad absorption band observed in the range of $3100-3600 \mathrm{~cm}^{-1}$ highlights the presence of hydroxyl groups in the deposited films: water absorption $\left(3250 \mathrm{~cm}^{-1}\right), \mathrm{O}-$ $\mathrm{H}$ vibration of associated $\mathrm{Si}-\mathrm{OH}\left(3450 \mathrm{~cm}^{-1}\right)$ and isolated $\mathrm{Si}-\mathrm{OH}$

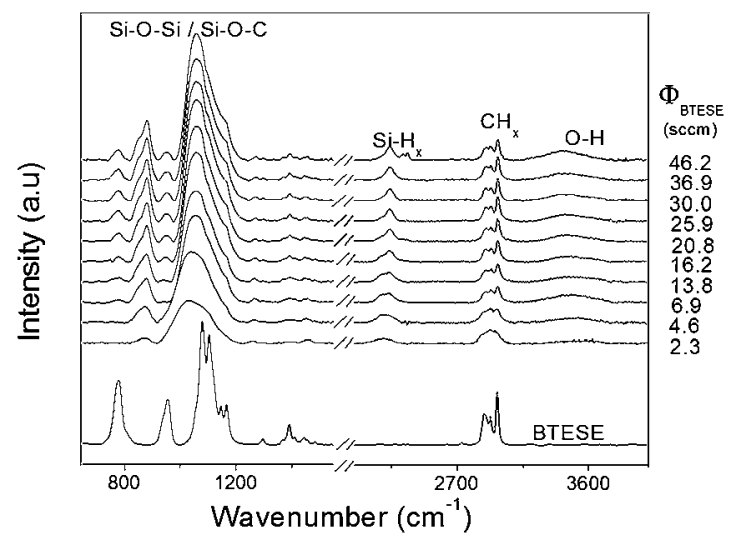

Fig. 3 FTIR spectra of plasma deposited hybrid silica films with the indicated values of $\Phi_{\text {BTESE. }}$
Table 1 Band assignment of FTIR spectra, $v=$ stretching, $\delta=$ bending, $\omega=$ wagging, $\rho=$ rocking, $a=$ asymmetric, and $s=$ symmetric

\begin{tabular}{|c|c|c|}
\hline \multicolumn{2}{|c|}{ Peak position $\left(\mathrm{cm}^{-1}\right)$} & \multirow[b]{2}{*}{ Assignments } \\
\hline BTESE & Film & \\
\hline - & $3200-3700$ & $v(\mathrm{O}-\mathrm{H})$, free $\mathrm{Si}-\mathrm{OH}$ \\
\hline 2980 & 2980 & va $\mathrm{C}-\mathrm{H} 3, \mathrm{sp}^{3} \mathrm{CH}_{3}$ \\
\hline 2930 & 2930 & va $\mathrm{C}-\mathrm{H} 2, \mathrm{sp}^{3} \mathrm{CH}_{2}$ \\
\hline 1883 & 1883 & vs $\mathrm{C}-\mathrm{H} 2, \mathrm{sp}^{3} \mathrm{CH}_{2}$ \\
\hline - & 2239 & vs $\mathrm{O}_{x} \mathrm{Si}-\mathrm{Hy}$ \\
\hline - & 2170 & vs $\mathrm{C}_{x} \mathrm{Si}-\mathrm{Hy}$ \\
\hline $1483-1443$ & 1483-1443 & $\delta\left(\mathrm{CH}_{2}\right), \delta\left(\mathrm{CH}_{3}\right)$ in -OEt \\
\hline $1360-1410$ & $1360-1410$ & $\mathrm{\delta a}\left(\mathrm{CH}_{2}\right), \mathrm{Si}-\mathrm{CH}_{2}-\mathrm{CH}_{2}-\mathrm{Si}$ \\
\hline 1295 & 1295 & $\omega\left(\mathrm{CH}_{2}\right)$ in $\mathrm{Si}-\mathrm{CH}_{2}-\mathrm{CH}_{2}-\mathrm{Si}$ \\
\hline - & 1270 & $\delta \mathrm{s}\left(\mathrm{CH}_{3}\right)$ in $\mathrm{CH}_{3}-\mathrm{Si}(\mathrm{O})_{3}$ \\
\hline - & 1260 & $\delta \mathrm{s}\left(\mathrm{CH}_{3}\right)$ in $\left(\mathrm{CH}_{3}\right)_{2}-\mathrm{Si}(\mathrm{O})_{2}$ \\
\hline - & 1250 & $\delta \mathrm{s}\left(\mathrm{CH}_{3}\right)\left(\mathrm{CH}_{3}\right)_{3}-\mathrm{SiO}$ \\
\hline 1165 & 1155 & va $\mathrm{O}-\mathrm{C}$, in -OEt \\
\hline 1146 & - & va $\mathrm{O}-\mathrm{C}$, in -OEt \\
\hline 1105 & 1105 & va $\mathrm{Si}-\mathrm{O}-\mathrm{C}$, in $-\mathrm{O}-\mathrm{Et}$ \\
\hline 1080 & - & va $\mathrm{Si}-\mathrm{O}-\mathrm{C}$, in -OEt \\
\hline - & 1069 & va $\mathrm{Si}-\mathrm{O}-\mathrm{Si}, \mathrm{Si}-\mathrm{O}-\mathrm{Si} \approx 144^{\circ}$ \\
\hline & $1033-1008$ & va $\mathrm{Si}-\mathrm{O}-\mathrm{Si}, \mathrm{Si}-\mathrm{O}-\mathrm{Si}<144^{\circ}$ \\
\hline 958 & 958 & $\delta \mathrm{Si}-\mathrm{OH}, \rho\left(\mathrm{C}-\mathrm{CH}_{3}\right)$ \\
\hline - & 880 & $\delta \mathrm{Si}-\mathrm{O}-\mathrm{Si}$ \\
\hline - & 840 & $\rho\left(\mathrm{CH}_{3}\right)$ in $\mathrm{Si}-\left(\mathrm{CH}_{3}\right)_{1,2}$ \\
\hline 775 & 775 & $\rho\left(\mathrm{CH}_{2}\right)$, in $-\mathrm{OEt}$ \\
\hline
\end{tabular}

groups ( $3640 \mathrm{~cm}^{-1}$ ) probably formed from the reaction between ambient water vapor and $\mathrm{Si}-\mathrm{O}$ groups. ${ }^{52}$ The presence of $-\mathrm{OH}$ groups in the deposited films is confirmed by the $\mathrm{Si}-\mathrm{OH}$ bending at $950 \mathrm{~cm}^{-1}$. However, a contribution of this mode to the peak at around $955 \mathrm{~cm}^{-1}$ and corresponding to the rocking vibration of the $\mathrm{C}-\mathrm{CH}_{3}$ group in $\mathrm{O}-\mathrm{C}_{2} \mathrm{H}_{5}$ is possible. Increasing $\Phi_{\text {BTESE }}$ in the plasma leads to a more porous film as witnessed from the more intense $\mathrm{Si}-\mathrm{OH}$ absorption.

$\mathrm{Si}-\mathbf{H}_{x}$ groups. The $\mathrm{Si}-\mathrm{H}_{x}$ stretching absorption is detected in the range of $2240-2170 \mathrm{~cm}^{-1}$ in the FTIR spectra of all the films and absent in the reference spectrum of BTESE. This absorption band has been deconvoluted, Fig. 4, by means of two Gaussian contributions centered at 2172 and $2230 \mathrm{~cm}^{-1}$ and related to $\mathrm{H}_{-}$ $\mathrm{SiO}_{3}$ and $\mathrm{H}-\mathrm{Si}-\mathrm{C}_{x}(x=1,2)$ bonds, respectively. ${ }^{22}$ It can be seen that for the film deposited using a monomer flow rate of 2.3 sccm, the peaks corresponding to $\mathrm{H}-\mathrm{SiO}_{3}$ and $\mathrm{H}-\mathrm{Si}-\mathrm{C}_{x}$ have shifted to slightly higher wavenumbers. The reason of this shift is unclear and might be the manifestation of a different statistical distribution of elements around the silicon atom. The increase in the area of $\mathrm{H}-\mathrm{SiO}_{3}$ at the expense of $\mathrm{H}-\mathrm{Si}-\mathrm{C}_{x}$ clearly indicates the incorporation of oxygen atoms while the carbon content decreases. This finding confirms the trend of the refractive index and the absorption coefficient.

Si-O-Si groups. The Si-O-Si asymmetric stretching mode can be deconvoluted into at least four peaks. ${ }^{53}$ The deconvolution of the FTIR absorption band in the region 950-1200 $\mathrm{cm}^{-1}$ for some selected films deposited using different $\Phi_{\text {BTESE }}$ values is shown in Fig. 5. Although the peaks at 1113 and $1155 \mathrm{~cm}^{-1}$ overlap with those corresponding to the $\mathrm{Si}-\mathrm{O}-\mathrm{C}$ adsorption band of the BTESE precursor, ${ }^{54}$ those centered at 1033 and $1069 \mathrm{~cm}^{-1}$ can be ascribed solely to Si-O-Si stretching modes 


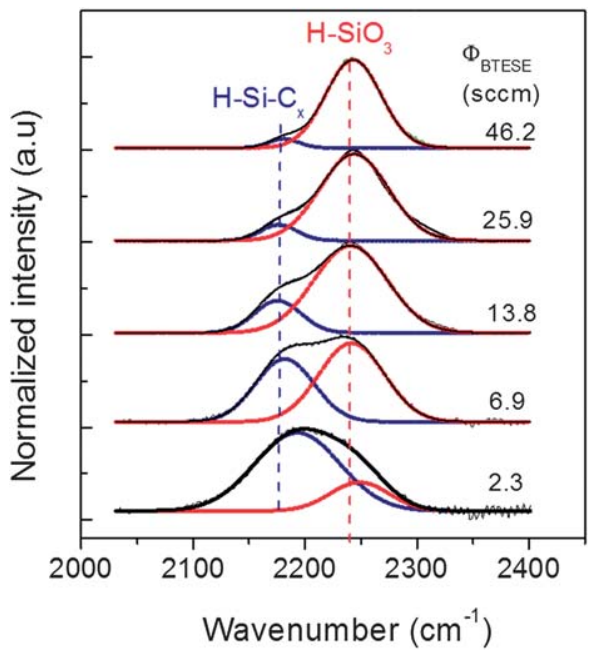

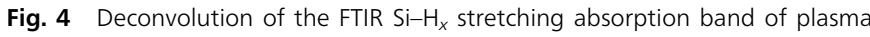
deposited hybrid silica films using different $\Phi_{\text {BTESE }}$ values.

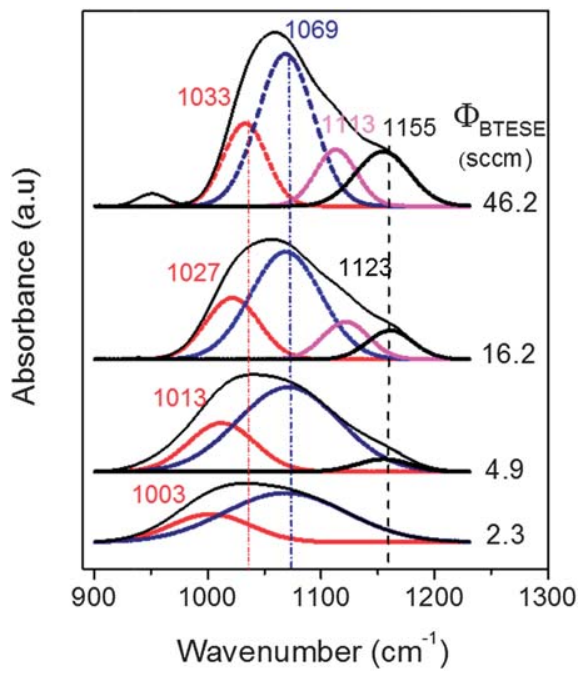

Fig. 5 Deconvolution of the FTIR Si-O-Si asymmetric stretching of some selected hybrid silica films deposited using different $\Phi_{\text {BTESE }}$ values.

with different bond angles. The peak at $1069 \mathrm{~cm}^{-1}$ can be assigned to the stretching of $\mathrm{Si}-\mathrm{O}-\mathrm{Si}$ bonds in a network structure with a bond angle close to $144^{\circ}$, while the peak at approximately $1033 \mathrm{~cm}^{-1}$ can be attributed to the stretching of $\mathrm{Si}-\mathrm{O}-\mathrm{Si}$ bonds with a smaller angle, similar to those encountered in sub-oxide films. ${ }^{22}$ The increase in the area of both peaks (sub-oxide and network) with increasing $\Phi_{\text {BTESE }}$ (Fig. 5) points to an increasing oxygen content in the film. Thermal $\mathrm{SiO}_{2}$, grown at temperatures higher than $1000^{\circ} \mathrm{C}$, displays a maximum FTIR absorption band at around $1080 \mathrm{~cm}^{-1}$, corresponding to the Si$\mathrm{O}-\mathrm{Si}$ asymmetric stretching band with a $\mathrm{Si}-\mathrm{O}-\mathrm{Si}$ bond angle of about $144^{\circ} .^{55}$ Moreover, a shift from 1080 to $1065 \mathrm{~cm}^{-1}$ was also observed $^{55}$ when the deposition temperature was decreased from 1000 to $700{ }^{\circ} \mathrm{C}$ as a consequence of the decrease in the Si$\mathrm{O}-\mathrm{Si}$ bond angle. In low temperature silicon sub-oxide $\left(\mathrm{SiO}_{x} x<\right.$ 2) films grown by PECVD using an $\mathrm{N}_{2} \mathrm{O}-\mathrm{SiH}_{4}$ mixture and $\mathrm{He}$ as dilution gas, the same authors ${ }^{56}$ reported a shift of the $\mathrm{Si}-\mathrm{O}-\mathrm{Si}$ asymmetric stretching mode from 1020 to $1062 \mathrm{~cm}^{-1}$ with increasing He dilution flow. The increased $\mathrm{Si}-\mathrm{O}-\mathrm{Si}$ bonding angle was ascribed to the decrease in $\mathrm{Si}-\mathrm{H}$ incorporation at the benefits of oxygen. A frequency shift of asymmetric Si-O-Si stretching bonds was also reported ${ }^{57}$ for carbon-incorporated $\mathrm{SiO}_{2}$ films deposited by PECVD. By developing a bonding structure model based on the electronegativity of an atom, these authors explained the observed red-shift (from 1060 to 1030 $\mathrm{cm}^{-1}$ ) by the decrease of the $\mathrm{Si}-\mathrm{O}-\mathrm{Si}$ bond angle influenced by the Si-C bond. Therefore, the blue-shift of the silicon sub-oxide peak with increased $\Phi_{\text {BTESE }}$, Fig. 5 , can be explained by the increase in the $\mathrm{Si}-\mathrm{O}-\mathrm{Si}$ bond angle as a consequence of the gradual reduction of the non-oxygen compounds, most probably C, surrounding the silicon.

Carbonaceous groups. The $\mathrm{Si}-\left(\mathrm{CH}_{3}\right)_{x}$ band is of great importance in FTIR spectra of organosilicon films because it can be used to determine the degree of oxidation of silicon atoms. For instance, a peak at around $1250 \mathrm{~cm}^{-1}$ indicates a mono-substituted group (M), i.e. $\mathrm{OSi}\left(\mathrm{CH}_{3}\right)_{3}$, while peaks at $\sim 1260$ and $\sim 1270 \mathrm{~cm}^{-1}$ are assigned to the di- (D) and tri- (T) substituted groups, respectively. ${ }^{58}$ Fig. 6 shows the deconvolution of the Si- $\left(\mathrm{CH}_{3}\right)_{x}$ absorption band of some selected films deposited at different $\Phi_{\text {BTESE }}$. At lower $\Phi_{\text {BTESE }}$ values, the bonding environment around the silicon is distributed between $\mathrm{M}, \mathrm{D}$, and $\mathrm{T}$ groups, although $\mathrm{D}$ moieties are dominant.

By increasing $\Phi_{\mathrm{BTESE}}$ a transition from a D-rich structure to a $\mathrm{T}$-rich one occurs and the disappearance of the $\mathrm{M}$ groups at the benefit of T groups is noticed. Further increase of $\Phi_{\mathrm{BTESE}}$ results in an increase of $\mathrm{T}$ groups at the expense of $\mathrm{D}$ ones, confirming the inclusion of more oxygen atoms in the film at the expense of carbon atoms. Fig. 7a shows the FTIR spectra in the region between 1350 and $1500 \mathrm{~cm}^{-1}$. The fitting of the absorption band in this region reveals the presence of peaks associated with $\mathrm{CH}_{2}$ deformation in Si- $\mathrm{CH}_{2}-\mathrm{CH}_{2}-\mathrm{Si}\left(1360-1410 \mathrm{~cm}^{-1}\right)^{43-51}$ and $\mathrm{CH}_{3}$

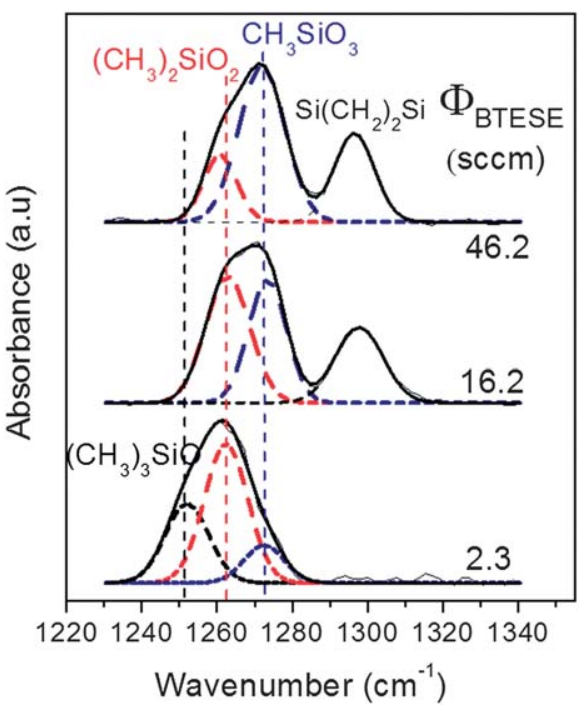

Fig. 6 Deconvolution of the FTIR Si- $\left(\mathrm{CH}_{3}\right)_{x}$ symmetric stretching band of some selected films deposited using different $\Phi_{\text {BTESE }}$ values. 

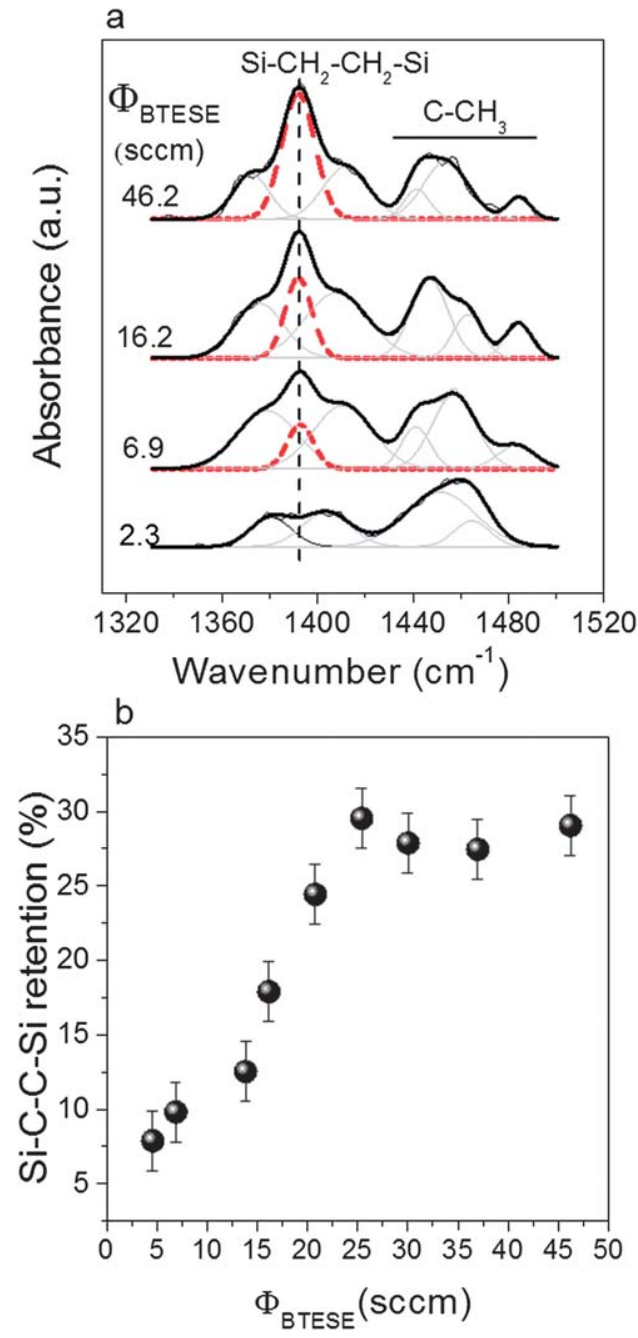

Fig. 7 Deconvolution (a) of the FTIR absorption band of some selected films in the region $1300-1500 \mathrm{~cm}^{-1}$, and evolution (b) of the intensity of the deconvoluted peaks at $1391 \mathrm{~cm}^{-1}$ as a function of $\Phi_{\text {BTESE. }}$

deformation vibrations in the $-\mathrm{OCH}_{2} \mathrm{CH}_{3}$ groups $(1440-1480$ $\left.\mathrm{cm}^{-1}\right) .^{43-51}$ The retention percentage of the ethylene bridge was evaluated by using the following formula

$$
\mathrm{RT}=\frac{A_{\text {film }}\left(1390 \mathrm{~cm}^{-1}\right)}{A_{\mathrm{BTESE}}\left(1390 \mathrm{~cm}^{-1}\right)} \times 100 \%
$$

Where $A_{\text {film }}$ and $A_{\mathrm{BTESE}}$ are the areas of the peaks located at 1390 $\mathrm{cm}^{-1}$ for the film and the liquid BTESE monomer, respectively. From Fig. $7 \mathrm{~b}$, it can be seen that almost $30 \%$ of the $\mathrm{Si}_{-} \mathrm{CH}_{2}-$ $\mathrm{CH}_{2}-\mathrm{Si}$ group is preserved from the original monomer structure. This identification is confirmed by the increase of the $\mathrm{CH}_{2}$ wagging vibration in $\mathrm{Si}-\mathrm{CH}_{2}-\mathrm{CH}_{2}-\mathrm{Si}^{49,50}$ as $\Phi_{\text {BTESE }}$ increases.

\section{Film chemical (XPS) analysis}

The surface composition of the films was determined by XPS. Fig. 8 shows the variation of the $\mathrm{Si}, \mathrm{C}$ and $\mathrm{O}$ atomic concentrations as a function of $\Phi_{\mathrm{BTESE}}$. By increasing the $\Phi_{\mathrm{BTESE}}$, the carbon content in the films decreases from $58 \%$ to $30 \%$. The oxygen content in the films changes from $25 \%$ to $48 \%$, while

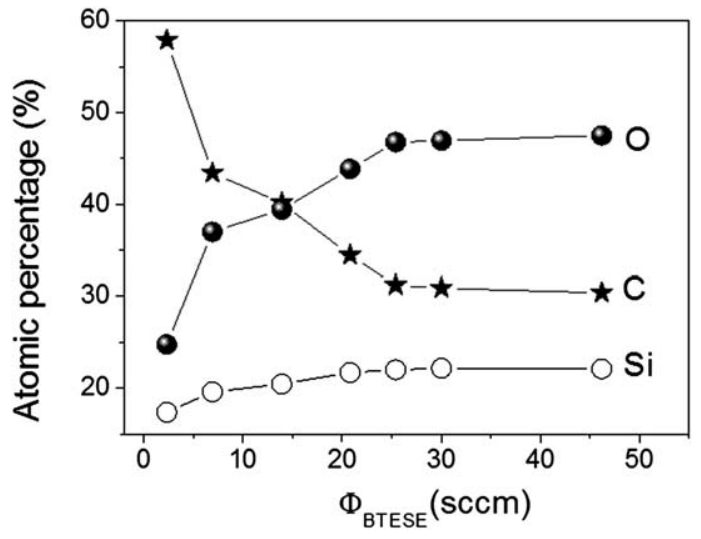

Fig. 8 Variation of the atomic percentage of the deposited films, determined by XPS, as a function of $\Phi_{\text {BTESE. }}$

the percentage of silicon barely changes, i.e. from $18 \%$ to $22 \%$. Fig. 9a shows the Si2p photoemission spectra of some selected films deposited for different $\Phi_{\text {BTESE }}$ values. It can be seen that the Si2p peak is shifted by around $1 \mathrm{eV}$ to higher binding energy values as $\Phi_{\mathrm{BTESE}}$ increases from 2.3 to $46.2 \mathrm{sccm}$.

This shift is associated with a change in the chemical state of the silicon atom because of the replacement of covalently bonded carbon atoms by oxygen. The four chemically distinct $\mathrm{Si}$ atoms are assigned as follows: $\mathrm{M}(100.8 \mathrm{eV}), \mathrm{D}(101.8 \mathrm{eV}), \mathrm{T}$ $(102.6 \mathrm{eV})$, and $\mathrm{Q}(103.5 \mathrm{eV}) .{ }^{59}$ The position and the FWHM of each component are kept constant $(1.5 \mathrm{eV})$ during the fitting. The evolution of the atomic percentage of the deconvoluted peaks as a function of $\Phi_{\text {BTESE }}$ is displayed in Fig. 9b. The increase of the inorganic moieties $\left(\mathrm{SiO}_{4}\right.$ and $\left.\mathrm{XSiO}_{3}\right)$ at the expense of the organic ones $\left(\mathrm{X}_{3} \mathrm{SiO}\right.$ and $\left.\mathrm{X}_{2} \mathrm{SiO}_{2}\right)$ clearly indicates the reduction of the carbon content as $\Phi_{\text {BTESE }}$ increases. Therefore, the transition from D-rich structure to T-rich one with increasing $\Phi_{\text {BTESE }}$ as observed during the FTIR measurements is confirmed by the XPS measurements. It is worth mentioning that the composition of the deposited films,
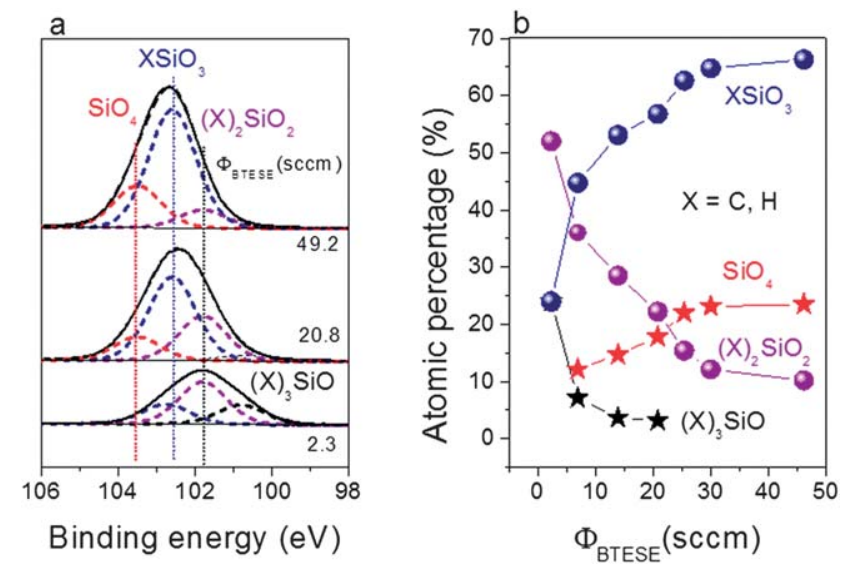

Fig. 9 Deconvolution (a) of the XPS Si2p core-shell of films deposited using different $\Phi_{\text {BTESE }}$ values, and variation (b) of the atomic percentage of the deconvoluted peaks as a function of $\Phi_{\mathrm{BTESE}}$. 


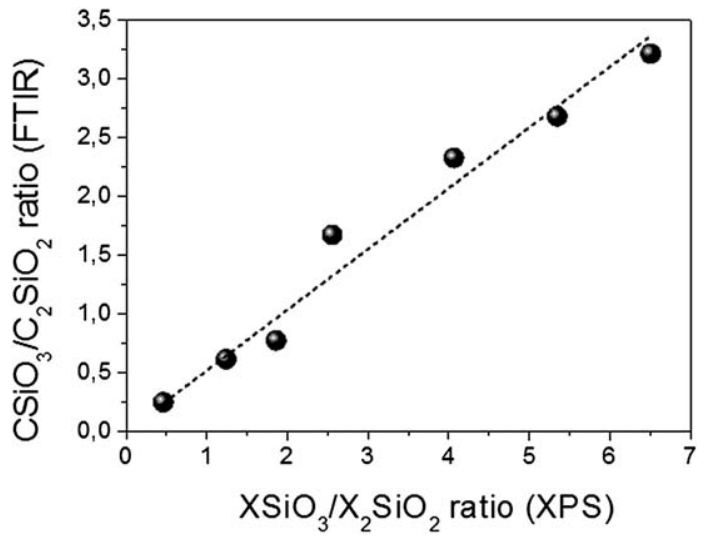

Fig. 10 Variation of the $\mathrm{CSiO}_{3} / \mathrm{C}_{2} \mathrm{SiO}_{2}$ ratio determined by FITR as a function of $\mathrm{XSiO}_{3} / \mathrm{X}_{2} \mathrm{SiO}_{2}$ ratio obtained by XPS.

determined by XPS, was the same when deposited on silicon wafer or porous polyamide-imide support.

The linearity between the $\mathrm{XSiO}_{3} / \mathrm{X}_{2} \mathrm{SiO}_{2}$ ratio, determined by XPS, and the $\mathrm{CSiO}_{3} / \mathrm{C}_{2} \mathrm{SiO}_{2}$ ratio, obtained by FTIR (Fig. 10), confirms the accuracy of both techniques for the determination of the chemical surroundings of the silicon atom.

The deconvolution of the C1s core-level spectra of the deposited films by means of four Gaussian contributions corresponding to $\mathrm{C}-\mathrm{C}(284.5 \mathrm{eV}), \mathrm{C}-\mathrm{Si}(283.5 \mathrm{eV}), \mathrm{C}-\mathrm{O}(286.5)$ and $\mathrm{C}=\mathrm{O}(288 \mathrm{eV})^{59}$ is displayed in Fig. 11a. The variation of the deconvoluted peaks as a function of $\Phi_{\text {BTESE }}$ is reported in Fig. 11b. It can be seen that a small number of carbonyl groups $(\mathrm{C}=\mathrm{O})$ are present in films deposited using $\Phi_{\text {BTESE }}$ lower than $20.8 \mathrm{sccm}$. Although the presence of these species was not detected by FTIR their presence can be ascribed to the high reactivity of the BTESE monomer with $\left(\mathrm{Ar}^{+}, \mathrm{e}^{-}\right)$species present in the plasma. The decrease of the carbon content as $\Phi_{\mathrm{BTESE}}$ increases is confirmed by the decrease of the atomic percentage of $\mathrm{C}-\mathrm{Si}$ groups, while the increase of $\mathrm{C}-\mathrm{O}$ groups points to less fragmentation of the BTESE monomer.
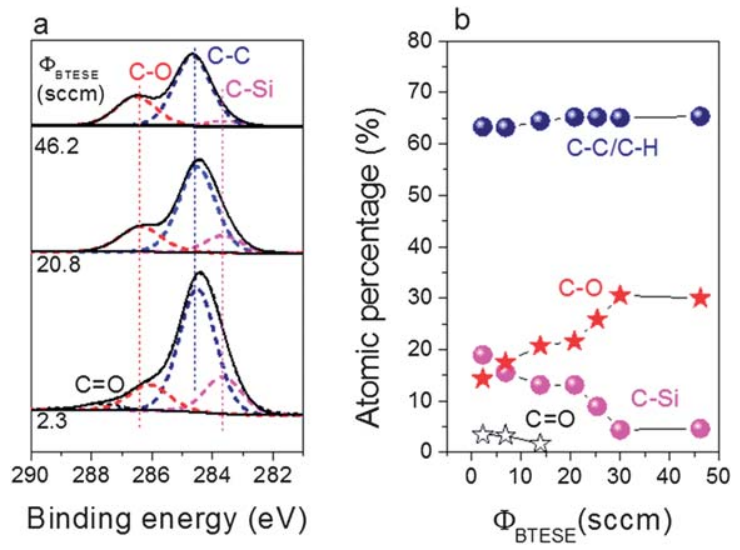

Fig. 11 Deconvolution (a) of the XPS C1s core-shell of films deposited for different $\Phi_{\text {BTESE }}$ values, and variation (b) of the atomic percentage of the deconvoluted peaks as a function of $\Phi_{\text {BTESE. }}$.

\section{Quantitative chemical analysis}

The density of the deposited films was assessed from the number of $\mathrm{Si}, \mathrm{C}$ and $\mathrm{O}$ atoms per surface area, determined by means of Rutherford back scattering, and their thickness obtained by means of spectroscopic ellipsometry. From Table 2, it can be seen that by increasing $\Phi_{\text {BTESE}}$, the C-to-Si ratio decreases from 3.99 to 1.18 , the O-to-Si ratio slightly increases from 1.82 to 2.09 and the film density decreases from 1.52 to $0.88 \mathrm{~g} \mathrm{~cm}^{-3}$. By comparing the obtained densities with that of thermal silicon dioxide $\left(2.2 \mathrm{~g} \mathrm{~cm}^{-3}\right)$ and the optical analysis shown earlier (Fig. 2b), it can be concluded that the increase in BTESE flow rate induces a decrease in carbon content and mass density, while the oxygen content is found to increase.

In conclusion, on the basis of FTIR, XPS and RBS analyses, the film deposited using $\Phi_{\text {BTESE }}=2.3 \mathrm{sccm}$ appears to be composed of polysiloxane chains in different bonding arrangements including $\mathrm{XSiO}_{3}, \mathrm{X}_{2} \mathrm{SiO}_{2}$ and $\mathrm{X}_{3} \mathrm{SiO}_{3},\left(\mathrm{X}=\mathrm{CH}_{3}, \mathrm{H}\right)$ due to a high dissociation of BTESE in the plasma. The presence of species like $\mathrm{Si}-\left(\mathrm{CH}_{3}\right)_{x}$ which are not present in the initial BTESE molecule structure points to the possible dissociation of $\mathrm{Si}-\mathrm{CH}_{2}-{ }^{-},-\mathrm{CH}_{2}-\mathrm{CH}_{2}-$, Si-O and $-\mathrm{OCH}_{2} \mathrm{CH}_{3}$ groups. By increasing the monomer flow, the fragmentation of the BTESE molecule decreased as noticed by the increase in $-\mathrm{OCH}_{2} \mathrm{CH}_{3}$, $\mathrm{Si}-\mathrm{H}$ and $\mathrm{Si}-\mathrm{CH}_{2}-\mathrm{CH}_{2}-\mathrm{Si}$ groups.

\section{Contact angle}

The hydrophobicity of the deposited layers can be evaluated by measuring the water contact angle which is an important parameter for the prediction of the wettability. The variation of the water contact angle as a function of $\Phi_{\mathrm{BTESE}}$ is reported in Table 2 . The pristine polyamide-imide support is characterized by the lowest contact angle, $64^{\circ}$. By increasing $\Phi_{\text {BTESE }}$ from 2.3 to $46.2 \mathrm{sccm}$, the contact angle decreases from 91 to $71^{\circ}$. This can be presumably attributed to the decrease in carbon content. Therefore, the decrease of the contact angle with increasing $\Phi_{\text {BTESE }}$ confirms that the blue-shift of the Si-O-Si asymmetric stretching with increasing $\Phi_{\mathrm{BTESE}}$ is due to the gradual reduction of the carbon surrounding the silicon.

\section{Membrane pervaporation performance}

The separation performance of the polyamide-imide (PAI) supported hybrid silica films was determined by the pervaporation of a water- $n$-butanol ( $5 \mathrm{wt} \% / 95 \mathrm{wt} \%$ ) mixture. The thickness of the selective hybrid silica layer was determined by means of

Table 2 Elemental composition (determined by RBS), film density and water contact angle $\left(\theta_{\text {water }}\right)$ of films deposited using different $\Phi_{\text {BTESE }}$

\begin{tabular}{lllll}
\hline$\Phi_{\text {BTESE }}(\mathrm{sccm})$ & $\theta_{\text {Water }}(\mathrm{deg})$. & $\mathrm{C} / \mathrm{Si}$ & $\mathrm{O} / \mathrm{Si}$ & Density $\left(\mathrm{g} \mathrm{cm}^{-3}\right)$ \\
\hline $\mathrm{PAI}^{a}$ & 64 & - & - & - \\
2.3 & 91 & 3.99 & 1.82 & 1.52 \\
13.8 & 82 & 1.57 & 1.97 & 1.31 \\
25.9 & 78 & 1.3 & 2 & 1.17 \\
46.2 & 71 & 1.18 & 2.09 & 0.88
\end{tabular}

${ }^{a}$ PAI refers to the pristine polyamide-imide support. 


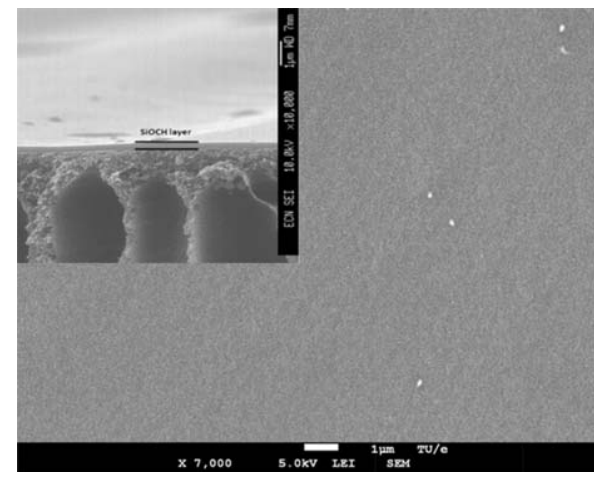

Fig. 12 SEM picture of the hybrid silica film deposited on the polyamide-imide substrate. The insert corresponds to the cross-sectional SEM image of the polymeric membrane, showing the polyamide-imide support and the $200 \mathrm{~nm}$ thick hybrid silica top layer.

scanning electron microscopy (SEM). A typical micrograph of the cross-section of the hybrid silica/polyamide-imide membrane is shown in Fig. 12 and the $200 \mathrm{~nm}$ thick plasma deposited top layer can be clearly observed (see insert Fig. 12). A dense, uniform and defect free top layer with a perfect adhesion to the porous polyamide-imide sub-layer is deposited.

The performances of various deposited films are reported in Table 3. The results were obtained at $95{ }^{\circ} \mathrm{C}$ after 4 days of continuous operation, allowing a more precise comparison of fluxes and selectivities. From Table 3, it can be seen that the water-butanol separation factor for the polymeric support is only 4.1. This very low value does not indicate a significant divergence from the distillation selectivity, and we can conclude that the support is non-selective. The water flux, $4 \mathrm{~kg} \mathrm{~m}^{-2} \mathrm{~h}^{-1}$, is low and shows that the transport resistance over the support is high. Transport resistance of the support can easily be decreased by choosing a more porous type, provided a defectfree layer can be deposited on top of it. Coating the PAI substrate with a $200 \mathrm{~nm}$ thick organically bridged silica layer drastically improves the water selectivity, while the water flux was found to increase with increasing $\Phi_{\mathrm{BTESE}}$, but the values were all below the one of the pristine PAI substrate. Although only a selected number of membranes have been tested, some preliminary conclusions can be already drawn. First, as $\Phi_{\mathrm{BTESE}}$ increases both the thickness of the membrane layer and the water flux increase. If the physical and chemical properties of

Table 3 Water flux $\left(J_{\mathrm{H}_{2} \mathrm{O}}\right)$, water concentration in the permeate $\left(W_{\mathrm{p}}\right)$ and separation factor $\left(\alpha_{\mathrm{w} / \mathrm{b}}\right)$ after 4 days of continuous membrane operation in $95 / 5$ $w t \% n$-butanol-water pervaporation $\left(95^{\circ} \mathrm{C}\right)$

\begin{tabular}{lllll}
\hline & \multicolumn{4}{l}{$\Phi_{\mathrm{BTESE}}(\mathrm{sccm})$} \\
\cline { 2 - 5 } & $\mathrm{PAI}^{a}$ & 13.8 & 25.9 & 46.2 \\
\hline$\rho\left(\mathrm{g} \mathrm{cm}^{-3}\right)$ & & 1.31 & 1.17 & 0.88 \\
$e(\mathrm{~nm})$ & 1000 & 200 & 325 & 400 \\
$J_{\mathrm{H}_{2} \mathrm{O}}\left(\mathrm{kg} \mathrm{m}^{-2} \mathrm{~h}^{-1}\right)$ & 4.0 & 1.15 & 1.77 & 2.23 \\
$W_{\mathrm{p}}(\mathrm{wt} \%)$ & 17.6 & 98.28 & 98.35 & 95.27 \\
$\alpha_{\mathrm{w} / \mathrm{b}}$ & 4.1 & 1090 & 1133 & 382.7
\end{tabular}

${ }^{a}$ PAI refers to the pristine polyamide-imide support.

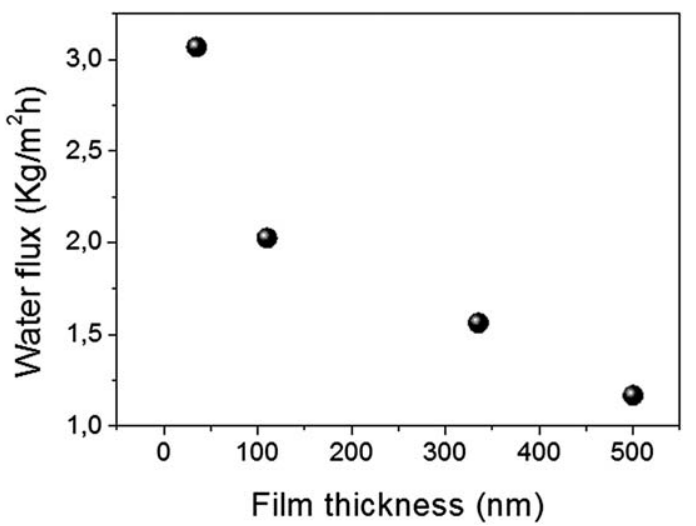

Fig. 13 Variation of the water flux as a function of the film thickness for the hybrid silica layer deposited using $\Phi_{\mathrm{BTESE}}=25.9 \mathrm{sccm}$.

the selective layer are constant throughout the membrane and independent of the thickness, i.e. a plausible assumption, an increasing thickness is normally associated with a decreased water flux as displayed in Fig. 13. This is caused by an increased resistance through the selective layer. Therefore, the increase of the water flux with $\Phi_{\text {BTESE }}$ can clearly be ascribed to less densification of the film. Moreover, the decrease of the water contact angle with increasing $\Phi_{\text {BTESE }}$ clearly shows that the water adsorption is negatively influenced by the hydrophobicity of the deposited layers. The decrease of both the carbon content and the film density is likely to enhance the water flux. The differences in the separation factor when the film density increases from 1.31 to $1.17 \mathrm{~g} \mathrm{~cm}^{-3}$ are within the experimental error. Therefore, it is difficult to draw any solid conclusion. When the layer is deposited using a monomer flow of $46.2 \mathrm{sccm}$, the separation factor drastically decreases to 382.7 . This high decrease of the separation factor can be ascribed to a less molecular sieve effect of the deposited layer which can be correlated with its low density.

\section{Benchmarking}

The pervaporation properties of the best plasma-deposited hybrid silica layer were benchmarked with two commercial ceramic membranes used in pervaporation by the end-users. $\mathrm{HybSi}^{{ }^{60}}$ is a tubular ceramic-supported hybrid organically bridged silica layer manufactured by the Energy Research Center of the Netherlands, while silica (Pervatech) ${ }^{4}$ is a tubular ceramic-supported silica layer supplied by Pervatech BV, Enter, the Netherlands. It is worth mentioning that the benchmarking with commercial membranes is carried out as preliminary evaluation of the performance of the plasma-deposited hybrid layer. It definitely does not represent an application test, which would require further optimization of the performance of the membrane. The tubular support is made from $\alpha$ - and $\gamma$ alumina. The macroporous $\alpha$-alumina provides mechanical strength, whereas the intermediate $\gamma$-alumina reduces the pore size in order to obtain a defect-free top layer. As reported in Table 4, the pervaporation separation index (PSI $\left.=J_{\mathrm{H}_{2} \mathrm{O}} \alpha_{\mathrm{w} / \mathrm{b}}\right)$ was used as an indicator of the performance of the deposited 
Table 4 Pervaporation performance of the plasma-deposited hybrid silica layer and two commercial membranes in the separation of $n$-butanol-water

\begin{tabular}{|c|c|c|c|}
\hline & \multicolumn{3}{|c|}{ Membranes } \\
\hline & This work & Silica $^{4}$ & $\operatorname{HybSi}{ }^{60}$ \\
\hline$W_{\mathrm{F}}^{a}(\mathrm{wt} \%)$ & 5 & 9.4 & 5 \\
\hline$J_{\mathrm{H}_{2} \mathrm{O}}\left(\mathrm{kg} \mathrm{m}^{-2} \mathrm{~h}^{-1}\right)$ & 1.77 & 4.14 & $2.0-3.6$ \\
\hline$T\left({ }^{\circ} \mathrm{C}\right)$ & 95 & 75 & 95 \\
\hline$W_{\mathrm{p}}(\mathrm{wt} \%)$ & 98.35 & 97.20 & 99.6 \\
\hline$\alpha_{\mathrm{w} / \mathrm{b}}$ & 1133 & 340 & 4700 \\
\hline PSI & 2005 & 1407 & 16920 \\
\hline
\end{tabular}

layers $^{61}$ and the following trend can be observed $\mathrm{HybSi}{ }^{\circledR}>$ this work $>$ silica (Pervatech). By means of RBS the composition and the density of the supported hybrid silica layer of the commercial $\mathrm{HybSi}{ }^{\circledR}$ membrane were found to be $\mathrm{SiC}_{1.17} \mathrm{O}_{1.95}$ and $2.11 \mathrm{~g} \mathrm{~cm}^{-3}$, respectively. The high density of the $\mathrm{HybSi}^{\circledR}$ membrane combined with its low carbon content compared to our best ETP-CVD made film, $1.17 \mathrm{~g} \mathrm{~cm}^{-3}$ and $\mathrm{C} / \mathrm{Si}=1.3$, could be the reason for its better pervaporation performance.

\section{Conclusions}

Hybrid organically bridged silica layers were successfully deposited from an Ar-BTESE mixture on porous polyamideimide substrates using the ETP-CVD technique. The film deposition has been carried out by tuning the BTESE-to-argon ion ratio. Increasing the monomer flow rate, $\Phi_{\mathrm{BTESE}}$, considerably changed the film structure and composition as indicated by SE, FTIR, XPS and RBS analyses. At low $\Phi_{\text {BTESE }}$ values, films appeared carbon rich because of the high fragmentation of the BTESE monomer, which resulted in the formation of $\mathrm{Si}-(\mathrm{CH})_{x}$ and $\mathrm{H}-\mathrm{Si}-\mathrm{C}_{x}$ chemical structures. However, at high BTESE flow rates, the structure of BTESE was partially preserved as noticed by the increase in intensity of $\mathrm{Si}-\mathrm{O}-\mathrm{C}$ moieties and the retention of approximately $30 \%$ of the $\mathrm{Si}-\mathrm{CH}_{2}-\mathrm{CH}_{2}-\mathrm{Si}$ bridges in the silica network. Increasing the $\Phi_{\mathrm{BTESE}}$ also induced a decrease of the film density from 1.52 to $0.88 \mathrm{~g} \mathrm{~cm}^{-3}$. The tunability of the film composition and microstructure by adjusting $\Phi_{\text {BTESE }}$ strongly affects the pervaporation properties. Compared with the pristine PAI, hybrid organically bridged silica/polyamide-imide membranes showed an improved separation factor ascribed to the molecular sieve effect of the deposited layer. The increase of the water flux as the BTESE flow rate increases was ascribed to both the decrease of the film density and the carbon content of the layers. The decrease of the film density reduces the transport resistance through the membrane, whereas the water adsorption is favored by the decrease of hydrophobicity of the deposited layers. The best pervaporation performance was obtained with a hybrid silica film deposited using a monomer flow of $25.9 \mathrm{sccm}$ and corresponding to a water flux of $\sim 1.8 \mathrm{~kg}$ $\mathrm{m}^{-2} \mathrm{~h}^{-1}$, a water concentration in the permeate higher than $98 \%$ and a separation factor of $>1100$. The plasma deposited layer shows a comparable $n$-butanol dehydration performance with commercial ceramic membranes. The obtained preliminary separation results show that inorganic-organic hybrid permselective layers can be successfully deposited by means of ETP-CVD. As reported in the literature for $\mathrm{HybSi}{ }^{\circledR}$ membranes, the presence of the organic bridge can be used as an indication of the possible organic solvent resistance of the deposited films, although specific tests should be performed with respect to the stability.

\section{Acknowledgements}

The Dutch Ministry of Economic Affairs/Agentschap NL is greatly acknowledged for its financial contribution within the EOS LT program, Project EOS LT 10011763.

\section{Notes and references}

1 P. D. Chapman, T. Oliveira, A. G. Livingston and K. Li, J. Membr. Sci., 2008, 318, 5.

2 W. Kujawski, M. Waczynski and M. Lasota, Sep. Sci. Technol., 1996, 31, 953.

3 A. M. Urtiaga, C. Casado, C. Aragoza and I. Ortiz, Sep. Sci. Technol., 2003, 38, 3473.

4 S. Sommer and T. Melin, Chem. Eng. Process., 2005, 44, 1138. 5 T. Gallego-Lizon, E. Edwards, G. Lobiundo and L. F. dos Santos, J. Membr. Sci., 2002, 197, 309.

6 V. Van Hoof, C. Dotremont and A. Buekenhoudt, Sep. Purif. Technol., 2006, 48(3), 304.

7 R. Kreiter, M. D. A. Rietkerk, B. C. Bonekamp, H. M. van Veen, V. G. Kessler and J. F. Vente, J. Sol-Gel Sci. Technol., 2008, 48, 203.

8 J. Sekulic, J. E. ten Elshof and D. H. A Blank, Langmuir, 2005, 21, 508.

9 J. Geens, B. Van der Bruggen and C. Vandecasteele, Chem. Eng. Sci., 2004, 59, 1161.

10 K. Vanherck, P. Vandezande, S. O. Aldea and I. F. J. Vankelecom, J. Membr. Sci., 2008, 320, 468.

11 M. Sairam, X. X. Loh, Y. Bhole, I. Sereewatthanawut, K. Li, A. Bismarck, J. H. G Steinke and A. G. Livingston, J. Membr. Sci., 2010, 349, 123.

12 W. Kujawski, S. Krajewska, M. Kujawski, L. Gazagnes, A. Larbot and M. Persin, Desalination, 2007, 205, 75.

13 C. Picard, A. Larbot, F. Guida-Pietrasanta, B. Boutevin and A. Ratsimihety, Sep. Purif. Technol., 2001, 25, 65.

14 H. M. van Veen, M. D. A. Rietkerk, D. P. Shanahan, M. M. A. van Tuel, R. Kreiter, H. L. Castricum, J. E. ten Elshof and J. F. Vente, J. Membr. Sci., 2011, 380, 124.

15 M. Kanezashi, K. Yada, T. Yoshioka and T. Tsuru, J. Membr. Sci., 2010, 348, 310.

16 G. Dubois, W. Volksen, T. Magbitang, R. D. Miller, D. M. Gage and R. H. Dauskardt, Adv. Mater., 2007, 19, 3989. 17 H. L. Castricum, G. G. Paradis, M. C. Mittelmeijer-Hazeleger, R. Kreiter, J. F. Vente and J. E. ten Elshof, Adv. Funct. Mater., 2011, 21, 2319.

18 G. G. Paradis, R. Kreiter, M. M. A. van Tuel, A. Nijmeijer and J. F. Vente, J. Mater. Chem., 2012, 22, 7258.

19 B. C. Bonekamp, A. van Horssen, L. A. Correia, J. F. Vente and W. G. Haije, J. Membr. Sci., 2006, 278, 349. 
20 A. Grill and V. Patel, J. Appl. Phys., 2008, 104, 803.

21 M. Wang, R. Rusli, J. L. Xie, N. Babu, C. Y. Li and K. Rakesh, J. Appl. Phys., 2004, 96, 829.

22 A. Grill and D. A. Neumayer, J. Appl. Phys., 2003, 94, 6697.

23 Y. Y. Ji, H. K. Chang, Y. C. Hong and S. H. Lee, Jpn. J. Appl. Phys., 2008, 47, 4691.

24 S. M. Park, D. J. Kim, S. I. Kim and N. E. Lee, J. Vac. Sci. Technol., A, 2008, 26, 949.

25 P. A. Premkumar, S. A. Starostin, M. Creatore, H. de Vries, R. M. J. Paffen, P. M. Koenraad and M. C. M. van de Sanden, Plasma Processes Polym., 2010, 7, 639.

26 M. van Hest, B. Mitu and D. C. Schram, Thin Solid Films, 2004, 449, 52.

27 T. Zaharia, P. Kudlacek, M. Creatore, R. Groenen, P. Persoone and M. C. M. van de Sanden, Diamond Relat. Mater., 2011, 20, 1266.

28 S. V. Singh, T. Zaharia, M. Creatore, R. Groenen, K. Van Hege and M. C. M. van de Sanden, J. Appl. Phys., 2010, 107, 013305.

29 I. Volintiru, M. Creatore, B. J. Kniknie, C. I. M. A. Spee and M. C. M. van de Sanden, J. Appl. Phys., 2007, 102, 043709.

30 I. Volintiru, M. Creatore and M. C. M. van de Sanden, J. Appl. Phys., 2008, 103, 033704.

31 F. J. H. van Assche, W. M. M. Kessels, R. Vangheluwe, W. S. Mischke, M. Evers and F. Ab, Thin Solid Films, 2005, 484, 46.

32 M. Creatore, M. Kilic, K. O'Brien, R. Groenen and M. C. M. van de Sanden, Thin Solid Films, 2003, 427, 137.

33 M. Creatore, J. C. Cigal, G. M. W. Kroesen and M. C. M. van de Sanden, Thin Solid Films, 2005, 484, 104.

34 Y. Barrell, M. Creatore, M. Schaepkens, C. D. Iacovangelo, T. Miebach and M. C. M. van de Sanden, Surf. Coat. Technol., 2004, 180, 367.

35 M. Creatore, S. M. Rieter, Y. Barrell, M. C. M. van de Sanden, R. Vernhes and L. Martinu, Thin Solid Films, 2008, 516, 8547.

36 M. Creatore, Y. Barrell, J. Benedikt and M. C. M. van de Sanden, Plasma Sources Sci. Technol., 2006, 15, 421.

37 M. Creatore, W. M. M. Kessels, Y. Barrell, J. Benedikt and M. C. M. van de Sanden, Mater. Sci. Semicond. Process., 2004, 7, 283.

38 H. L. Castricum, R. Kreiter, H. M. van Veen, D. H. A. Blank, J. F. Vente and J. E. ten Elshof, J. Membr. Sci., 2008, 324, 111.

39 H. L. Castricum, A. Sah, R. Kreiter, D. H. A. Blank, J. F. Vente and J. E. ten Elshof, Chem. Commun., 2008, 1103.

40 H. L. Castricum, A. Sah, R. Kreiter, D. H. A. Blank, J. F. Vente and J. E. ten Elshof, J. Mater. Chem., 2008, 18, 2150.
41 G. Beamson and D. Briggs, High resolution XPS of organic polymers, Willey, 1992.

42 M. van Hest, J. R. Haartsen, M. H. M. van Weert, D. C. Schram and M. C. M. van de Sanden, Plasma Sources Sci. Technol., 2003, 12, 539.

43 B. Schneider, J. Stokr, P. Schmidt, M. Mihailov, S. Dirlikov and N. Peeva, Polymer, 1979, 20, 705.

44 G. Das, P. Bettotti, L. Ferraioli, R. Raj, G. Mariotto, L. PaveSib and G. D. Soraru, Vib. Spectrosc., 2007, 45, 61.

45 Y. Ohashi, N. Tajima, Y. Xu, T. Kada, S. Nagano, H. Shimizu and S. Hasaka, Jpn. J. Appl. Phys., 2010, 49, 05FF02.

46 H. Shimizu, N. Tajima, T. Kada, S. Nagano, Y. Ohashi and S. Hasaka, Jpn. J. Appl. Phys., 2010, 49, 05FF03.

47 D. D. Burkey and K. K. Gleason, J. Appl. Phys., 2003, 93, 5143.

48 T. B. Casserly and K. K. Gleason, Plasma Processes Polym., 2005, 2, 679.

49 A. Dabrowski, M. Barczak, N. V. Stolyarchuk, I. V. Melnyk and Y. L. Zub, Adsorption, 2005, 11, 501.

50 N. V. Stolyarchuk, I. V. Mel'nik, Y. L. Zub, M. Barczak, A. Dabrowski and B. Alonso, Prot. Met. Phys. Chem. Surf., 2009, 45, 169.

51 H. A. Szymanski and R. E. Erickson, Infrared band handbook, IFI/Plenum, London, 2nd edn, 1970.

52 S. F. Durrant, F. P. M. Rouxinol, R. V. Gelamo, B. C. Transferetti, C. U. Davanzo and M. A. B. De Moraes, Thin Solid Films, 2008, 516, 806.

53 S. C. Deshmukh and E. S. Aydil, J. Vac. Sci. Technol., B, 1996, 14, 738.

54 C. Y. Wang, Z. X. Shen and J. Z. Zheng, Appl. Spectrosc., 2000, 54, 209.

55 P. G. Pai, S. S. Chao, Y. Takagi and G. Lucovsky, J. Vac. Sci. Technol., A, 1986, 4, 689.

56 G. Lucovsky, M. J. Manitini, J. K. Srivastava and E. A. Irene, J. Vac. Sci. Technol., B: Microelectron. Process. Phenom., 1987, 5, 530.

57 Y. H. Kim, M. S. Hwang, H. J. Kim, J. Y. Kim and Y. Lee, J. Appl. Phys., 2001, 90, 3367.

58 D. D. Burkey and K. K. Gleason, J. Vac. Sci. Technol., A, 2004, 22, 61.

59 S. Roualdes, R. Berjoan and J. Durand, Sep. Purif. Technol., 2001, 25, 391.

60 R. Kreiter, M. D. A. Rietkerk, H. L. Castricum, H. M. van Veen, J. E. ten Elshof and J. F. Vente, ChemSusChem, 2009, 2, 158.

61 A. W. Verkerk, P. van Male, M. A. G. Vorstman and J. T. F. Keurentjes, Sep. Purif. Technol., 2001, 22, 689. 